\title{
Isolation and characterization of 2-butoxyethanol degrading bacterial strains
}

\author{
Christine Woiski (i) - Daniel Dobslaw (D) - Karl-Heinrich Engesser (i)
}

Received: 24 October 2019/Accepted: 10 April 2020/Published online: 30 April 2020

(C) The Author(s) 2020

\begin{abstract}
A total of 11 bacterial strains capable of completely degrading 2-butoxyethanol (2-BE) were isolated from forest soil, a biotrickling filter, a bioscrubber, and activated sludge, and identified by 16S rRNA gene sequence analysis. Eight of these strains belong to the genus Pseudomonas; the remaining three strains are Hydrogenophaga pseudoflava BOE3, Gordonia terrae BOE5, and Cupriavidus oxalaticus BOE300. In addition to 2-BE, all isolated strains were able to grow on 2-ethoxyethanol and 2-propoxyethanol, ethanol, $n$-hexanol, ethyl acetate, 2-butoxyacetic acid (2-BAA), glyoxylic acid, and $n$ butanol. Apart from the only gram-positive strain isolated, BOE5, none of the strains were able to grow on the nonpolar ethers diethyl ether, di- $n$-butyl ether, $n$-butyl vinyl ether, and dibenzyl ether, as well as on 1-butoxy-2-propanol. Strains H. pseudoflava BOE3 and two of the isolated pseudomonads, Pseudomonas putida BOE100 and $P$. vancouverensis BOE200, were studied in more detail. The maximum growth rates of
\end{abstract}

Electronic supplementary material The online version of this article (https://doi.org/10.1007/s10532-020-09900-3) contains supplementary material, which is available to authorized users.

C. Woiski $(\varangle) \cdot$ D. Dobslaw · K.-H. Engesser Department of Biological Waste Air Purification, Institute for Sanitary Engineering, Water Quality and Solid Waste Management, University of Stuttgart, Bandtaele 2, 70569 Stuttgart, Germany

e-mail: christine.woiski@iswa.uni-stuttgart.de strains BOE3, BOE100, and BOE200 at $30{ }^{\circ} \mathrm{C}$ were $0.204 \mathrm{~h}^{-1}$ at $4 \mathrm{mM}, 0.645 \mathrm{~h}^{-1}$ at $5 \mathrm{mM}$, and $0.395 \mathrm{~h}^{-1}$ at $6 \mathrm{mM}$ 2-BE, respectively. 2-BAA, $n$ butanol, and butanoic acid were detected as potential metabolites during the degradation of 2-BE. These findings indicate that the degradation of 2-BE by the isolated gram-negative strains proceeds via oxidation to 2-BAA with subsequent cleavage of the ether bond yielding glyoxylate and $n$-butanol. Since Gordonia terrae BOE5 was the only strain able to degrade nonpolar ethers like diethyl ether, the degradation pathway of 2-BE may be different for this strain.

Keywords 2-Butoxyethanol - Degradation pathway · Glycol ether · Pseudomonas . Hydrogenophaga $\cdot$ Gordonia $\cdot$ Cupriavidus

\section{Introduction}

2-Butoxyethanol (2-BE), also called ethylene glycol monobutyl ether, is a widely used organic compound, which does not occur naturally. It is classified as a 'High Production Volume Chemical' (HPVC) because of its considerable production volumes of approximately $161 \mathrm{kt} / \mathrm{a}$ in the EU (2003) and 45-227 kt/a in the USA (2002) (European Chemicals Bureau 2006; OECD 2004). 2-BE is mainly used as a solvent in surface coatings, paints, and varnishes, but also in 
lubricants, oils, and dyes. It is found in detergents and cleaning agents, printing inks, hydrofracking liquids, oil dispersants, textiles, hair dyes, cosmetics, pharmaceutical products, agricultural chemicals, herbicides, brake fluids, de-icers, and extinguishing foams, and also serves as a starting chemical for the production of other chemicals such as butyl glycol acetate or various plasticizers (Committee on Energy and Commerce U.S. House of Representatives 2011; Gooch 2007; IARC 2006; OECD 1997; U.S. EPA 2010). 2-BE is the main component of the oil dispersant Corexit EC9527A (Kover et al. 2014). 813,000 L of Corexit EC9527A were applied to the ocean surface during the 2010 Deepwater Horizon oil spill (BP Gulf Science Data 2014). Consequently, 2-BE has been, and continues to be, released into the environment in large quantities through various mechanisms. Due to its high water solubility, the relatively low vapor pressure, and the low soil adsorption potential, it is predominantly found in the aqueous phase. The environmental distribution of 2-BE was predicted to be as follows: water $84.2 \%$; air $11.4 \%$; soil $4.19 \%$; and sediment $0.132 \%$ (OECD 2004).

In mammals, ingested 2-BE is mainly oxidized by alcohol dehydrogenase and aldehyde dehydrogenase to 2-butoxyacetaldehyde and further to 2-butoxyacetic acid (2-BAA) (Aasmoe et al. 1998; ATSDR 1998; Bartnik et al. 1987; Boatman et al. 2014; Dean and Krenzelok 2008; Deisinger and Boatman 2004; Johanson and Johnsson 1991; Lockley et al. 2004; Rettenmeier et al. 1993; Udden and Patton 1994). 2-BAA and in some cases its glutamine and glycine conjugates were detected in urine and blood samples. Another route for the elimination of 2-BE is the conjugation with sulfate, glucuronic acid, or fatty acids (IARC 2006; Kaphalia et al. 1996). To a much lesser extent, dealkylation of 2-BE by cytochrome P450 2E1 (CYP 2E1) was observed. This reaction leads to the formation of butyraldehyde and ethylene glycol, which is further oxidized to oxalic acid (Rambourg-Schepens et al. 1988).

The degradation pathway for 2-BE in bacteria, however, has not yet been studied in detail. 2-BE is an aliphatic ether comprising a nonpolar alkyl residue on one side and a polar ethylene glycol residue on the other side. Primary degradation can occur by attacking either group. Different pathways for the aerobic degradation of ethylene glycol ethers (EGEs) like polyethylene glycol (PEG) or linear primary fatty alcohol ethoxylates (LAEs) on the one hand and linear and cyclic alkyl ethers (AEs) on the other hand have been proposed. They can provide information on the possible degradation route of 2-BE. The focus of this work is the 2-BE degradation under aerobic conditions. Therefore, anaerobic pathways were not considered.

Three different pathways for the degradation of PEG have been postulated. Most frequently, oxidation of the hydroxyl group to a carboxyl group was observed, followed by the cleavage of the ether bond yielding glyoxylate and PEG shortened by one glycol unit. Bacterial strains degrading PEG in this manner include Acinetobacter SC 25 and Pseudomonas KW 8 (degrading up to PEG 400), Flavobacterium BT 1 (up to PEG 1500) (Watson and Jones 1977), the gramnegative strains PG1, PG3, PG5, and PG6 (up to PEG 400) (Hosoya et al. 1978), Pseudonocardia sp. strain K1 (up to PEG 8000) (Kohlweyer et al. 2000; Yamashita et al. 2004a), Sphingomonas sp. N6 (up to PEG 20,000) (Kawai and Enokibara 1996), Sphingopyxis macrogoltabida (formerly Flavobacterium and Sphingomonas macrogoltabidus) strains 103 and 203 (up to PEG 4000) (Kawai and Yamanaka 1989; Takeuchi et al. 1993,2001; Yamanaka and Kawai 1989), and the mixed culture E-1 consisting of Sphingopyxis terrae (formerly Flavobacterium and Sphingomonas terrae) and Rhizobium sp. (formerly Pseudomonas) (up to PEG 20,000) (Kawai and Yamanaka 1986, 1989; Takeuchi et al. 2001). Two ether-cleaving enzymes have been identified, a PEG carboxylate dehydrogenase (PCDH) from $S$. terrae and S. macrogoltabida strains 103 and 203 (Somyoonsap et al. 2008; Tani et al. 2007), and a diglycolic acid dehydrogenase (DGADH) from Pseudonocardia sp. K1 (Yamashita et al. 2004a). The degradation of PEG by Pseudomonas stutzeri JA1001 (up to PEG 13,500) also occurs via oxidation of the alcohol to the corresponding acid with subsequent elimination of glyoxylate (Obradors and Aguilar 1991). However, it was suggested that a single enzyme catalyzes all three reaction steps at once. The (hypothetic) degradation of 2-BE according to this pathway is depicted in Fig. 1, route 1 .

Another degradation route was proposed by Pearce and Heydeman (1980) for Acinetobacter strain S8. First, a (hypothetical) vinyl ether intermediate is formed by the elimination of water. In the next step, water is added and the ether is cleaved yielding PEG 


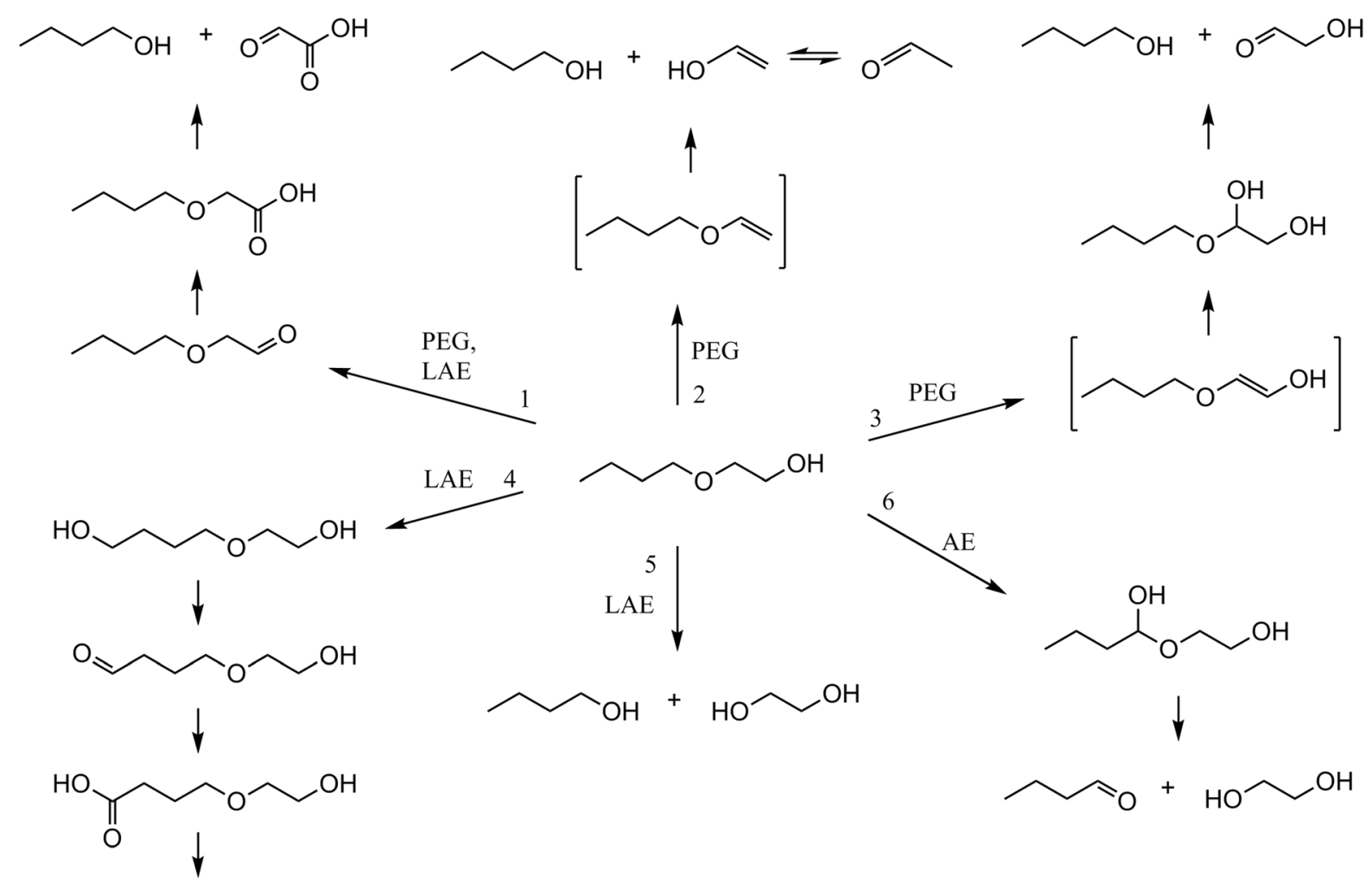

$\beta$-Oxidation

Fig. 1 Possible degradation pathways for 2-BE, according to the literature. Details can be found in the introduction.

shortened by one glycol unit, and vinyl alcohol, which is in tautomeric balance with acetaldehyde (Fig. 1, route 2).

Pathway no. 3 was proposed by Thélu et al. (1980) for the degradation of PEG 400 by Pseudomonas $\mathrm{P} 400$. After the formation of an enol ether, a hemiacetal is produced by water addition. The ether is cleaved thereafter, either spontaneously or by formation of an ester and subsequent hydrolysis (Fig. 1, route 3).

The breakdown of LAEs, which are used as nonionic surfactants, was examined by several groups and, again, three different primary attacks were observed (Schröder 2001). Degradation mechanisms were determined by the detection of metabolites. In some cases, intermediates have been found within one culture indicating that at least two of these pathways occur in parallel.

First, the alkyl chain is $\omega$ - and subsequently $\beta$ oxidized (Fig. 1, route 4), for example by a mixed culture including Pseudomonas putida TSh-18,
Pseudomonas putida TP-19, and Pseudomonas sp. OS-22 (Panchenko and Turkovskaya 2000) and by microorganisms within activated sludge (Patterson et al. 1967, 1970; Steber and Wierich 1985).

Second, the PEG moiety is attacked by oxidation of the hydroxyl group and oxidative shortening of the polyether chain, according to the first PEG degradation pathway mentioned. Strains Pseudomonas sp. RW1 (Corti et al. 1998), Enterobacter strain Z3 (Zembrzuska et al. 2016), and again the mixed culture including Pseudomonas putida TSh-18, Pseudomonas putida TP-19, and Pseudomonas sp. OS-22 (Panchenko and Turkovskaya 2000) are able to degrade LAEs in this manner (Fig. 1, route 1).

Third, central fission of the ether bond with the formation of a fatty alcohol and the PEG moiety took place in pure cultures of Pseudomonas sp. strain SC25A (Tidswell et al. 1996), Enterobacter strains Z2 and Z3, Citrobacter freundii strain Z4, Stenotrophomonas strain Z5 (Budnik et al. 2016; Zembrzuska et al. 
2016), a pseudomonad (Ichikawa et al. 1978), and also in activated sludge (Patterson et al. 1970; Sparham et al. 2008; Steber and Wierich 1985; Szymanski et al. 2002a, b; Tobin et al. 1976) (Fig. 1, route 5). Details about the ether cleavage are not known, although this mechanism seems to be widespread.

The degradation of nonpolar AE starts by hydroxylation of the c-atom adjacent to the ether bond, forming an unstable hemiacetal (Fig. 1, route 6). Different enzymes catalyzing this reaction have been described. Toluene 2-monooxygenase from Burkholderia cepacia G4/PR1 oxidizes diethyl ether, butyl methyl ether, and 2-chloroethyl ethyl ether (Hur et al. 1997). The cytochrome $\mathrm{P} 450$ monooxygenase Eth from Aquincola tertiaricarbonis L108 catalyzes the $O$-dealkylation of diethyl ether as well as of methyl tert-butyl ether (MTBE) (Schuster et al. 2013) and ammonia monooxygenase from Nitrosomonas europaea transforms dimethyl ether and diethyl ether (Hyman 1999). The same reaction type is assumed to occur in various strains of the genus Rhodococcus (Bock et al. 1996; Kim et al. 2007; Kim and Engesser 2004; Moreno-Horn et al. 2005; Tajima et al. 2012). Tetrahydrofuran (THF) degrading Pseudonocardia sp. K1, Pseudonocardia sp. strain ENV478, and Rhodococcus aetherivorans strain M8, as well as 1,4-dioxane degrading $P$. dioxanivorans CB1190, are also capable of growing on diethyl ether (Kohlweyer et al. 2000; Parales et al. 1994; Tajima et al. 2012; Vainberg et al. 2006). Different soluble di-iron monooxygenases (SDIMO) are involved in THF or 1,4-dioxane degradation, namely THF monooxygenase Thm, 1,4-dioxane monooxygenase Dxm, and propane monooxygenase Prm (Inoue et al. 2016; Thiemer et al. 2003). Pseudonocardia sp. strain ENV478 transformed bis(2-chloroethyl) ether only after growing on propane or THF (McClay et al. 2007). Therefore, it is very likely that SDIMOs act on diethyl ether as well.

As already mentioned, Pseudonocardia sp. K1 degrades PEG besides THF (Yamashita et al. 2004a). THF is cleaved by Thm (Inoue et al. 2016). PEG on the other hand is first oxidized to PEG carboxylate, and then cleaved by superoxide dismutase-like DGADH (Yamashita et al. 2004b). This strain thus degrades PEG and THF by two completely different pathways.

In summary, 6 different primary attacks were considered for the degradation of 2-BE analogous to the degradation of PEG, LAE and AE, which are presented in Fig. 1. The aim of this study was to isolate and characterize bacterial strains able to degrade 2-BE and to gain initial information about the degradation pathway.

\section{Materials and methods}

Culture media

The strains were cultivated in mineral salt medium (MM) consisting of (per liter) $\mathrm{KH}_{2} \mathrm{PO}_{4} 1 \mathrm{~g} ; \mathrm{Na}_{2}$ $\mathrm{HPO}_{4} \cdot 2 \mathrm{H}_{2} \mathrm{O} 3.5 \mathrm{~g} ;\left(\mathrm{NH}_{4}\right)_{2} \mathrm{SO}_{4} 1 \mathrm{~g} ; \mathrm{MgSO}_{4} \cdot 7 \mathrm{H}_{2} \mathrm{O}$ $200 \mathrm{mg}$; $\mathrm{Ca}\left(\mathrm{NO}_{3}\right)_{2} \cdot 4 \mathrm{H}_{2} \mathrm{O} 50 \mathrm{mg} ; \mathrm{Fe}(\mathrm{III}) \mathrm{NH}_{4}$-citrate $10 \mathrm{mg} ; \mathrm{H}_{3} \mathrm{BO}_{3} 0.3 \mathrm{mg} ; \mathrm{CoCl}_{2} \cdot 6 \mathrm{H}_{2} \mathrm{O} 0.2 \mathrm{mg} ; \mathrm{ZnSO}_{4}$. $7 \mathrm{H}_{2} \mathrm{O} 0.1 \mathrm{mg} ; \mathrm{MnCl}_{2} \cdot 4 \mathrm{H}_{2} \mathrm{O} 30 \mu \mathrm{g} ; \mathrm{NaMoO}_{4} \cdot 2 \mathrm{H}_{2} \mathrm{O}$ $30 \mu \mathrm{g} ; \mathrm{NiCl}_{2} \cdot 6 \mathrm{H}_{2} \mathrm{O} 20 \mu \mathrm{g} ; \mathrm{CuCl}_{2} \cdot 2 \mathrm{H}_{2} \mathrm{O} 10 \mu \mathrm{g}$ supplemented with a carbon source. MMB medium consists of MM with addition of $5 \mathrm{mM}$ 2-BE. Lysogenic broth (LB) contained (per liter) $10 \mathrm{~g}$ tryptone, $5 \mathrm{~g}$ yeast extract, and $10 \mathrm{~g} \mathrm{NaCl}$. For solid medium, $1.5 \%$ agar was added.

Isolation and identification of 2-BE degrading bacterial strains

Different samples were used as inocula for enrichment cultures: forest soil, samples from a biotrickling filter (both Stuttgart, Germany), samples from a bioscrubber (Rastatt, Germany), and activated sludge (Stuttgart and Karlsruhe, Germany). The biotrickling filter was used to clean air contaminated with 2-BE (Dobslaw et al. 2018). The bioscrubber removed VOCs in varying concentrations including butyl acetate, ethyl acetate, methyl ethyl ketone (MEK), acetone, dichloromethane (DCM), ethanol, methanol, isopropanol, THF, hexane, heptane, ethylbenzene, 2-BE, and others (Dobslaw et al. 2010). Approximately $2 \mathrm{~g}$ of each sample were transferred into $250 \mathrm{ml}$ flasks containing $50 \mathrm{ml} \mathrm{MM}$ medium and $3 \mathrm{mM} 2-\mathrm{BE}$ as the sole source of carbon. The flasks were incubated at $30{ }^{\circ} \mathrm{C}$ on a rotary shaker $(150 \mathrm{rpm})$ for one week. About $5 \mathrm{ml}$ of these cultures were transferred into flasks with fresh medium and incubated under the same conditions. After another transfer, dilutions of the cultures were plated on solid MMB and incubated at $30{ }^{\circ} \mathrm{C}$. Single colonies were spread on fresh plates to obtain pure strains. 
BOX PCR fingerprinting using primer BOXA1R (CTACGGCAAGGCGACGCTGACG) showed whether the isolated strains differ from each other (Martin et al. 1992; Versalovic et al. 1994). The strains were identified by amplification of parts of the $16 \mathrm{~S}$ rRNA gene using Primers 27F (AGAGTTTGATCMTGGCTCAG) and 1492R (TACGGYTACCTTGTTACGACTT) (Weisburg et al. 1991). The PCR products were purified using DNA Clean \& Concentrator-5 Kit (Zymo Research Europe GmbH, Freiburg, Germany). Sanger sequencing of the purified amplicons was performed by Microsynth Seqlab (Goettingen, Germany). To identify the strains, 16S rRNA gene sequences were analyzed using the BLAST program (Altschul et al. 1990). The sequences were deposited in GenBank under accession numbers MH580159 and MH580208-MH580217 for strains BOE1, BOE2, BOE3, BOE4, BOE5, BOE6, BOE7, BOE10, BOE100, BOE200, and BOE300, respectively.

A phylogenetic tree based on the 16S rRNA gene sequences of the isolated strains and closely related type strains was constructed by the Neighbor-Joining method (Saitou and Nei 1987) using MEGA7 (Kumar et al. 2016). The evolutionary distances were computed using the Maximum Composite Likelihood method (Tamura et al. 2004).

\section{Substrate utilization}

Different substrates were used for growth experiments to obtain information on the substrate versatility of the isolated strains and the possible degradation pathway of 2-BE. MM medium was inoculated with cells of the respective strain to obtain an optical density at $546 \mathrm{~nm}$ $\left(\mathrm{OD}_{546}\right)$ of at least 0.1 . Cell densities were measured using Pharmacia LKB Biotechnology Ultrospec III UV/Visible Spectrophotometer. $3 \mathrm{mM}$ of the following compounds were added as sole source of carbon: 2-BAA, glyoxylic acid, $n$-butanol, ethanol, $n$-hexanol, ethyl acetate, isopropanol, acetone, MEK, diethyl ether, di- $n$-butyl ether, $n$-butyl vinyl ether, dibenzyl ether, 2-ethoxyethanol, PEG 200, 2-propoxyethanol, 1-butoxy-2-propanol, 2-phenoxyethanol, hexane, cyclohexane, benzoic acid, styrene, and toluene. The cultures were incubated at $30{ }^{\circ} \mathrm{C}$ on a rotary shaker and cell densities were measured after one week.
Growth experiments

Liquid MMB was inoculated with cells of the strains H. pseudoflava BOE3, P. putida BOE100, or $P$. vancouverensis BOE200 grown on MM agar plates containing $7.6 \mathrm{mM}$ 2-BE. Cultures were incubated over night at $30{ }^{\circ} \mathrm{C}$ on a rotary shaker $(150 \mathrm{rpm})$. The next day, cultures were diluted with fresh medium to obtain an $\mathrm{OD}_{546}$ of $0.06-0.1$. 2-BE was added at different concentrations, and the $\mathrm{OD}_{546}$ was measured periodically. The experiments were conducted in triplicates.

\section{Salt tolerance}

$3.5 \%(w / v)$ sodium chloride was added to liquid MMB medium, approximately corresponding to the salinity of seawater, and growth was monitored to analyze the salt tolerance of strains BOE3, BOE100, and BOE200.

\section{Antibiotic resistance}

Strains BOE100 and BOE200 were spread on LB plates and strain BOE3 was spread on MMB plates, because it does not grow on LB plates. Sterile filter disks were placed on top. The following masses of different antibiotics were applied to the disks: chloramphenicol $(\mathrm{Cm}) 64 \mu \mathrm{g}$, tetracycline $12 \mu \mathrm{g}$, kanamycin $50 \mu \mathrm{g}$, ampicillin $50 \mu \mathrm{g}$, penicillin $50 \mu \mathrm{g}$, streptomycin $50 \mu \mathrm{g}$, nalidixic acid $50 \mu \mathrm{g}$. The plates were incubated at $30{ }^{\circ} \mathrm{C}$ for 1 day (BOE100), 2 days (BOE200), or 5 days (BOE3), as growth rates of the three strains examined varied. Thereafter, the size of the zone of inhibition was measured.

\section{Metabolite detection}

Cultures were grown over night in MMB medium. The next day, $10 \mathrm{mM}$ 2-BE were added and the cultures were incubated for another $3 \mathrm{~h}$. $\mathrm{Cm}$ was added to stop protein synthesis and the cultures were incubated overnight. The medium was centrifuged at $5000 \times g$ for $15 \mathrm{~min}$ at room temperature to remove cells. The supernatant was acidified with phosphoric acid to $\mathrm{pH} 2$ and extracted with an equal volume of DCM for $3 \mathrm{~min}$. Extracts were dried over anhydrous sodium sulfate and analyzed by GC-MS [Agilent Technologies; 7890A GC system, 5975C VL MSD detector, 7683B injector, VF-5 $\mathrm{ms}$ column $(60 \mathrm{~m} \times 0,25 \mathrm{~mm} \times 0,25 \mu \mathrm{m})]$. 
The temperature program was as follows: hold for $1 \mathrm{~min}$ at $40{ }^{\circ} \mathrm{C}$, increase to $200{ }^{\circ} \mathrm{C}$ at $10{ }^{\circ} \mathrm{C} \mathrm{min}{ }^{-1}$. $1 \mu \mathrm{l}$ was injected and the sample was analyzed in split mode (1:10). Helium was used as carrier gas at a flow rate of $0.927 \mathrm{ml} \mathrm{min}^{-1}$. The goal was to detect potential metabolites qualitatively, not quantitatively. Therefore, the creation of calibration curves was omitted.

\section{Results}

Isolation and identification of 2-BE degrading bacterial strains

In total, 11 distinct 2-BE degrading bacterial strains were isolated. As shown in Fig. 2, the BOX PCR fingerprint of each isolated strain was unique, which means the strains differ from each other. All strains are catalase-positive and oxidase-positive. On the basis of 16S rRNA gene sequence analysis, they were identified as Pseudomonas knackmussii BOE1, Pseudomonas putida BOE2, Hydrogenophaga pseudoflava BOE3, Pseudomonas umsongensis BOE4, Gordonia terrae BOE5, Pseudomonas extremaustralis BOE6, Pseudomonas plecoglossicida BOE7, Pseudomonas sp. BOE10, Pseudomonas putida BOE100, Pseudomonas vancouverensis BOE200, and Cupriavidus oxalaticus BOE300. Table 1 shows the origin of the isolated strains and the GenBank accession numbers of their corresponding $16 \mathrm{~S}$ rRNA gene sequences. The phylogenetic tree constructed on the basis of the 16S rRNA gene sequences of these strains and closely related type strains is shown in Fig. 3.

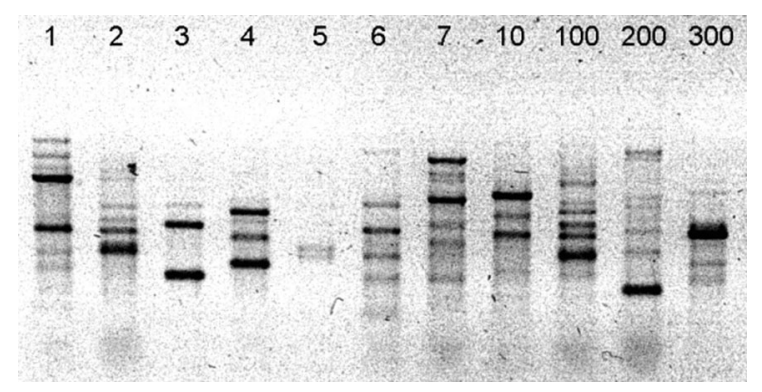

Fig. 2 BOX PCR fingerprinting showing that the isolated strains differ genetically from each other. 1 BOE1, 2 BOE2, 3 BOE3, 4 BOE4, 5 BOE5, 6 BOE6, 7 BOE7, 10 BOE10, 100 BOE100, 200 BOE200, 300 BOE300
Substrate utilization

Substrate utilization of the BOE strains is summarized in Table 2. All strains were able to grow on 2-BE and its possible degradation metabolites 2-BAA, glyoxylic acid, and $n$-butanol. Additionally, the alcohols ethanol and $n$-hexanol, the ester ethyl acetate, and the EGEs 2-ethoxyethanol and 2-propoxyethanol served as growth substrates. Unlike the other strains, BOE3 and BOE100 could grow on the further tested EGE PEG 200. Remarkably, only BOE5 grew on the nonpolar ethers diethyl ether, di- $n$-butyl ether, $n$-butyl vinyl ether, and dibenzyl ether, as well as on the propylene glycol ether 1-butoxy-2-propanol. 2-phenoxyethanol was used as growth substrate by strains BOE2 and BOE4. Isopropanol and acetone, the C3 substrates tested, served strains BOE5 and BOE300 as growth substrates. Strains BOE5, BOE6, BOE200, and BOE300 were able to grow on MEK. BOE2, BOE4, BOE5, BOE7, BOE100, BOE200, and BOE300 grew on benzoic acid. None of the strains were able to use either the (cyclo-)alkanes hexane and cyclohexane or the nonpolar aromatic compounds styrene and toluene as growth substrates.

Growth experiments

BOE3 was able to grow with $4 \mathrm{mM}, 6 \mathrm{mM}, 8 \mathrm{mM}$, and $10 \mathrm{mM}$ 2-BE with slightly decreasing growth rates during exponential phase of $0.204 \mathrm{~h}^{-1}$, $0.198 \mathrm{~h}^{-1}, 0.194 \mathrm{~h}^{-1}$, and $0.193 \mathrm{~h}^{-1}$, respectively. In comparison, BOE100 was able to grow faster and tolerated higher 2-BE concentration. The growth rates for 2-BE concentrations of $5 \mathrm{mM}, 7.5 \mathrm{mM}, 10 \mathrm{mM}$, $12.5 \mathrm{mM}$, and $15 \mathrm{mM}$ were $0.645 \mathrm{~h}^{-1}, 0.602 \mathrm{~h}^{-1}$, $0.565 \mathrm{~h}^{-1}, 0.538 \mathrm{~h}^{-1}$, and $0.514 \mathrm{~h}^{-1}$, respectively. BOE200 grew with 2-BE concentrations of $4 \mathrm{mM}$, $6 \mathrm{mM}, 8 \mathrm{mM}$, and $10 \mathrm{mM}$ at growth rates of $0.383 \mathrm{~h}^{-1}, 0.395 \mathrm{~h}^{-1}, 0.363 \mathrm{~h}^{-1}$, and $0.362 \mathrm{~h}^{-1}$. Accordingly, the highest growth rate $\left(0.645 \mathrm{~h}^{-1}\right)$ was achieved by BOE100 at a 2-BE concentration of $5 \mathrm{mM}$. Figure 4 shows the growth curves for strains BOE3, BOE100, and BOE200 for 2-BE concentrations of $4 \mathrm{mM}, 5 \mathrm{mM}$, and $6 \mathrm{mM}$, respectively, since these were the concentrations leading to the highest growth rates for each strain. BOE200 had a lag phase of about $4 \mathrm{~h}$, whereas growth occurred immediately for strains BOE3 and BOE100. Within the 2-BE concentration range tested, the consumption of $1 \mathrm{mM}$ 
Table 1 Isolated 2-BE degrading strains, their origin, and the GenBank accession no. of their 16S rRNA sequence

\begin{tabular}{llll}
\hline Bacterial strain & Gram & Inoculum & GenBank accession no \\
\hline Pseudomonas knackmussii BOE1 & Gram-negative & Forest soil, Stuttgart (Germany) & MH580159 \\
Pseudomonas putida BOE2 & Gram-negative & Forest soil, Stuttgart (Germany) & MH580208 \\
Hydrogenophaga pseudoflava BOE3 & Gram-negative & Forest soil, Stuttgart (Germany) & MH580209 \\
Pseudomonas umsongensis BOE4 & Gram-negative & Forest soil, Stuttgart (Germany) & MH580210 \\
Gordonia terrae BOE5 & Gram-positive & Biotrickling filter, Stuttgart (Germany) & MH580211 \\
Pseudomonas extremaustralis BOE6 & Gram-negative & Biotrickling filter, Stuttgart (Germany) & MH580212 \\
Pseudomonas plecoglossicida BOE7 & Gram-negative & Activated sludge, Karlsruhe (Germany) & MH580213 \\
Pseudomonas sp. BOE10 & Gram-negative & Activated sludge, Karlsruhe (Germany) & MH580214 \\
Pseudomonas putida BOE100 & Gram-negative & Bioscrubber, Rastatt (Germany) & MH580215 \\
Pseudomonas vancouverensis BOE200 & Gram-negative & Bioscrubber, Rastatt (Germany) & MH580216 \\
Cupriavidus oxalaticus BOE300 & Gram-negative & Activated sludge, Stuttgart (Germany) & MH580217 \\
\hline
\end{tabular}

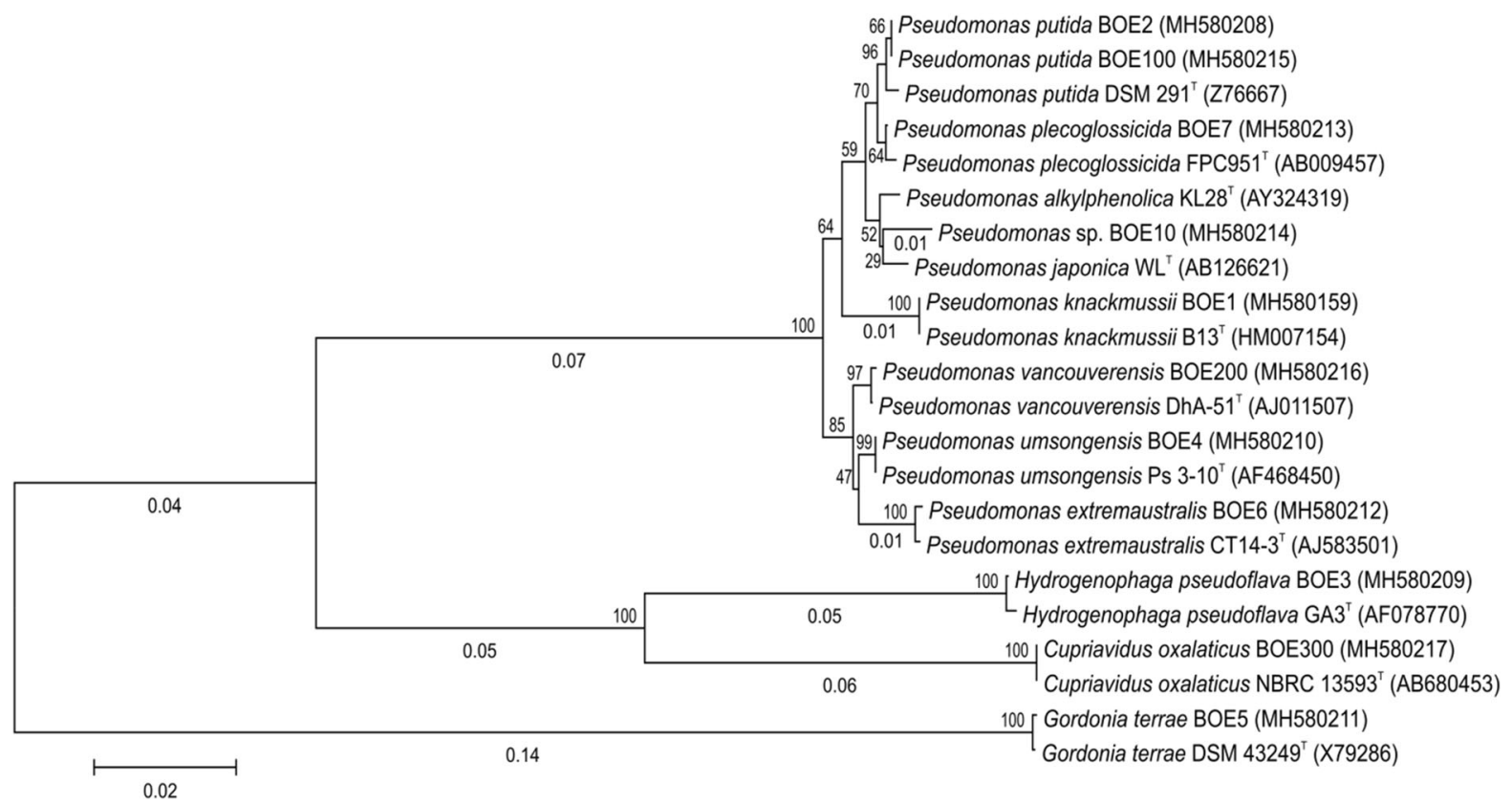

Fig. 3 Phylogenetic tree constructed by the Neighbor-Joining method (Saitou and Nei 1987) based on the 16S rRNA gene sequences of the isolated strains and closely related type strains (T). GenBank accession numbers are presented in parentheses. The percentage of replicate trees in which the associated taxa clustered together in the bootstrap test (1000 replicates) is shown next to the nodes. The tree is drawn to scale, with branch lengths (below the branches) in the same units as those of the

2-BE resulted in an average increase of $\mathrm{OD}_{546}$ of 0.227 for BOE3, 0.29 for BOE100, and 0.273 for BOE200.

Growth of strain BOE3 with $20 \mathrm{mM}, 30 \mathrm{mM}$, and $40 \mathrm{mM}$ 2-BE is depicted in Fig. 5, panels A-C. evolutionary distances used to infer the phylogenetic tree. The evolutionary distances were computed using the Maximum Composite Likelihood method (Tamura et al. 2004) and are in the units of the number of base substitutions per site. The scale bar represents 0.02 substitutions per nucleotide position. There were a total of 1265 positions in the final dataset. Evolutionary analyses were conducted in MEGA7 (Kumar et al. 2016)

$20 \mathrm{mM}$ 2-BE were consumed completely within 4 days and a maximum $\mathrm{OD}_{546}$ of about 3 was reached (panel A). At day 1, growth rates were $0.071-0.077 \mathrm{~h}^{-1}$. On days $1-4$, they slowed down to 
Table 2 Substrate utilization of the BOE strains

\begin{tabular}{|c|c|c|c|c|c|c|c|c|c|c|c|}
\hline Substrate & $\begin{array}{l}\text { BOE } \\
1\end{array}$ & $\begin{array}{l}\text { BOE } \\
2\end{array}$ & $\begin{array}{l}\text { BOE } \\
3\end{array}$ & $\begin{array}{l}\text { BOE } \\
4\end{array}$ & $\begin{array}{l}\text { BOE } \\
5\end{array}$ & $\begin{array}{l}\text { BOE } \\
6\end{array}$ & $\begin{array}{l}\text { BOE } \\
7\end{array}$ & $\begin{array}{l}\text { BOE } \\
10\end{array}$ & $\begin{array}{l}\text { BOE } \\
100\end{array}$ & $\begin{array}{l}\text { BOE } \\
200\end{array}$ & $\begin{array}{l}\text { BOE } \\
300\end{array}$ \\
\hline 2-BE & + & + & + & + & + & + & + & + & + & + & + \\
\hline 2-BAA & + & + & + & + & + & + & + & + & + & + & + \\
\hline Glyoxylic acid & + & + & + & + & + & + & + & + & + & + & + \\
\hline n-Butanol & + & + & + & + & + & + & + & + & + & + & + \\
\hline Ethanol & + & + & + & + & + & + & + & + & + & + & + \\
\hline$n$-Hexanol & + & + & + & + & + & + & + & + & + & + & + \\
\hline Ethyl acetate & + & + & + & + & + & + & + & + & + & + & + \\
\hline Isopropanol & - & - & - & - & + & - & - & - & - & - & + \\
\hline Acetone & - & - & - & - & + & - & - & - & - & - & + \\
\hline MEK & - & - & - & - & + & + & - & - & - & + & + \\
\hline Diethyl ether & - & - & - & - & + & - & - & - & - & - & - \\
\hline Di-n-butyl ether & - & - & - & - & + & - & - & - & - & - & - \\
\hline$n$-Butyl vinyl ether & - & - & - & - & + & - & - & - & - & - & - \\
\hline Dibenzyl ether & - & - & - & - & + & - & - & - & - & - & - \\
\hline 2-Ethoxyethanol & + & + & + & + & + & + & + & + & + & + & + \\
\hline PEG 200 & - & - & + & - & - & - & - & - & + & - & - \\
\hline 2-Propoxyethanol & + & + & + & + & + & + & + & + & + & + & + \\
\hline 1-Butoxy-2-propanol & - & - & - & - & + & - & - & - & - & - & - \\
\hline 2-Phenoxyethanol & - & + & - & + & - & - & - & - & - & - & - \\
\hline Hexane & - & - & - & - & - & - & - & - & - & - & - \\
\hline Cyclohexane & - & - & - & - & - & - & - & - & - & - & - \\
\hline Benzoic acid & - & + & - & + & + & - & + & - & + & + & + \\
\hline Styrene & - & - & - & - & - & - & - & - & - & - & - \\
\hline Toluene & - & - & - & - & - & - & - & - & - & - & - \\
\hline
\end{tabular}

Liquid MM medium was inoculated with the respective strain, $3 \mathrm{mM}$ substrate was added and the $\mathrm{OD}_{546}$ was measured after one week.+, $\mathrm{OD}_{546}$ increased by $\geq 0.2 ;-, \mathrm{OD}_{546}$ increased by $<0.2$ or decreased

about $0.02-0.027 \mathrm{~h}^{-1}$. Growth with $30 \mathrm{mM}$ and $40 \mathrm{mM}$ 2-BE was considerably slower and the three cultures for each concentration varied strongly in their pace of growth (panels $\mathrm{B}$ and $\mathrm{C}$ ). The growth rates were $0.032-0.04 \mathrm{~h}^{-1}$ on days $1-3,0.005-0.01 \mathrm{~h}^{-1}$ on days $3-8$, and $0-0.003 \mathrm{~h}^{-1}$ on days $8-17$ at $30 \mathrm{mM}$ 2-BE, and $0.021-0.026 \mathrm{~h}^{-1}$ on days $1-4$ and $0.001-0.007 \mathrm{~h}^{-1}$ on days $8-17$ at $40 \mathrm{mM} 2-\mathrm{BE}$. At these concentrations, growth was considerably inhibited and not reproducible and the $\mathrm{OD}_{546}$ did not exceed the value of 4 .

Panels D-F of Fig. 5 show the growth of strain BOE100 with $30 \mathrm{mM}, 40 \mathrm{mM}$, and $50 \mathrm{mM} \mathrm{2-BE.}$ $30 \mathrm{mM}$ 2-BE were degraded within 4-10 days (panel D). Growth rates were calculated to be ca.
$0.113-0.124 \mathrm{~h}^{-1}$ on day 1 and $0.008-0.019 \mathrm{~h}^{-1}$ on days $1-3$. The maximum $\mathrm{OD}_{546}$ was about 4.5 . At higher concentrations, growth rates declined substantially (day $1, \quad 0.087-0.104 \mathrm{~h}^{-1} ;$ days $1-4$, $0.008-0.012 \mathrm{~h}^{-1}$, days 8-18, 0.002-0.004 $\mathrm{h}^{-1}$ ) and the highest $\mathrm{OD}_{546}$ was 3 (panels $\mathrm{E}$ and F). 2-BAA was detected in the medium at day 4 and the $\mathrm{pH}$ was about 6. After 18 days, 2-BAA was completely removed and the $\mathrm{pH}$ increased to 7 . Growth between days 8 and 18 was limited, the $\mathrm{OD}_{546}$ increased only to a comparatively small extent from 1.3 to 2.5 with $40 \mathrm{mM} 2-\mathrm{BE}$, and from 1.1 to 2.3 with $50 \mathrm{mM}$ 2-BE.

Growth of strain BOE200 with $20 \mathrm{mM}, 30 \mathrm{mM}$ and $40 \mathrm{mM}$ 2-BE is shown in panels G-I. After 3 days, $20 \mathrm{mM} 2-\mathrm{BE}$ were consumed and the $\mathrm{OD}_{546}$ was about 


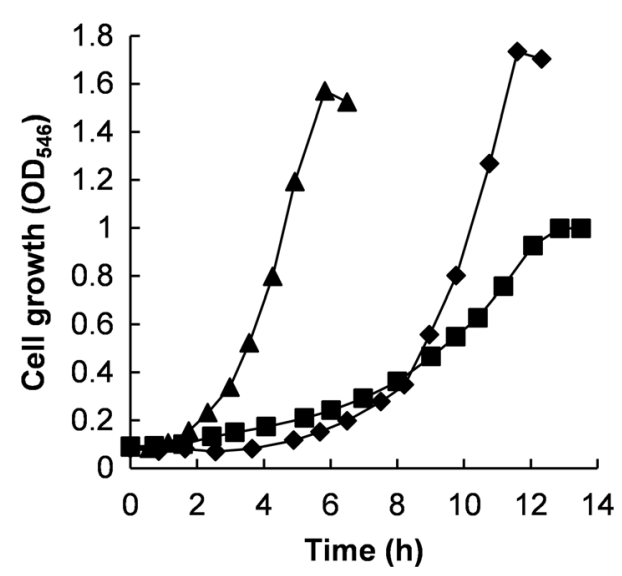

Fig. 4 Maximum cell growth of strains BOE3 at $4 \mathrm{mM} 2-\mathrm{BE}$ (squares), BOE100 at $5 \mathrm{mM}$ 2-BE (triangles), and BOE200 at $6 \mathrm{mM} 2-\mathrm{BE}$ (diamonds). At these concentrations, the maximum growth rates were obtained among all concentrations tested

3. Growth rates were $0.118-0.138 \mathrm{~h}^{-1}$ on day 1 and about $0.01 \mathrm{~h}^{-1}$ on days $1-3$. Growth rates at $30 \mathrm{mM}$ 2-BE were similar to those at $20 \mathrm{mM}$ until day 3 (day $1, \quad 0.109-0.13 \mathrm{~h}^{-1}$; days $1-3, \quad 0.004-0.009 \mathrm{~h}^{-1}$ ), although 2-BE was not degraded completely during this time (panel H). After 4 days, 2-BAA accumulated and $\mathrm{pH}$ dropped to approximately 6 , inhibiting further growth. This was already observed with BOE100. Panel I shows that $40 \mathrm{mM}$ 2-BE led up to an $\mathrm{OD}_{546}$ of about 2 within 4 days with growth rates of $0.107-0.118$ on day 1 and $0.003-0.004$ on days $1-4$. This was the highest $\mathrm{OD}_{546}$ reached and continued growth was hindered. Again, 2-BAA was detected in the medium and the $\mathrm{pH}$ was about 6. 2-BE and 2-BAA were completely removed after 18 days at both $40 \mathrm{mM}$ and $50 \mathrm{mM}$ initial concentrations, but slowly and, as already stated, without any additional growth.

Characterization of strains H. pseudoflava BOE3, $P$. putida BOE100, and P. vancouverensis BOE200

Strains BOE3, BOE100, and BOE200 are sensitive to $\mathrm{Cm}$, tetracycline, kanamycin, streptomycin, and nalidixic acid, as shown in Table 3 . Whereas strain BOE3 is susceptible to ampicillin and penicillin, the pseudomonads BOE100 and BOE200 are resistant to those two beta-lactam antibiotics.

As already mentioned in the introduction, 2-BE is the main component of Corexit EC9527A and 813,000 $\mathrm{L}$ of this dispersant were applied to the ocean surface during the 2010 Deepwater Horizon oil spill. Therefore, strains BOE3, BOE100 and BOE200 were studied for their ability to degrade 2-BE under marine conditions. Only strain BOE100 was able to grow in MMB containing 3.5\% NaCl (Fig. 6). Growth started after an adaption period of one day and the growth rate of $0.065 \mathrm{~h}^{-1}$ was considerably lower than in MMB without $\mathrm{NaCl}$. Strains BOE3 and BOE200 showed no growth under these conditions.

\section{Metabolite detection}

BOE100 was grown in liquid MMB and $\mathrm{Cm}$ was added during exponential growth to stop protein synthesis. $10 \mathrm{mM}$ 2-BE were added and the culture was incubated for another day. It was then centrifuged and the supernatant was extracted with DCM and analyzed by GC-MS. Figure 7 shows the chromatogram. In addition to the substrate 2-BE, 2-BAA, $n$-butanol, and butanoic acid were detected as potential intermediates of the 2-BE degradation pathway.

\section{Discussion}

11 bacterial strains capable of degrading 2-BE were isolated from soil, activated sludge from different waste water treatment plants, a biotrickling filter, and a bioscrubber, and identified as Pseudomonas knackmussii BOE1, Pseudomonas putida BOE2, Hydrogenophaga pseudoflava BOE3, Pseudomonas umsongensis BOE4, Gordonia terrae BOE5, Pseudomonas extremaustralis BOE6, Pseudomonas plecoglossicida BOE7, Pseudomonas sp. BOE10, Pseudomonas putida BOE100, Pseudomonas vancouverensis BOE200, and Cupriavidus oxalaticus BOE300. Among these strains, only G. terrae BOE5 is gram-positive, and 8 out of the 10 gram-negative strains are pseudomonads. All strains were catalasepositive and oxidase-positive. Isolated from very different sources and locations, Pseudomonas seemed to be the dominant genus harboring the 2-BE degradation capacity in the environment.

In the past, many Pseudomonas strains have been isolated degrading a broad variety of organic molecules including alkanes (Rojo 2009; van Beilen and Funhoff 2007; Wang et al. 2017), aromatic compounds (Arias et al. 2008; Jindrová et al. 2002; Mooney et al. 2006; Peng et al. 2008), nonpolar ethers like THF 

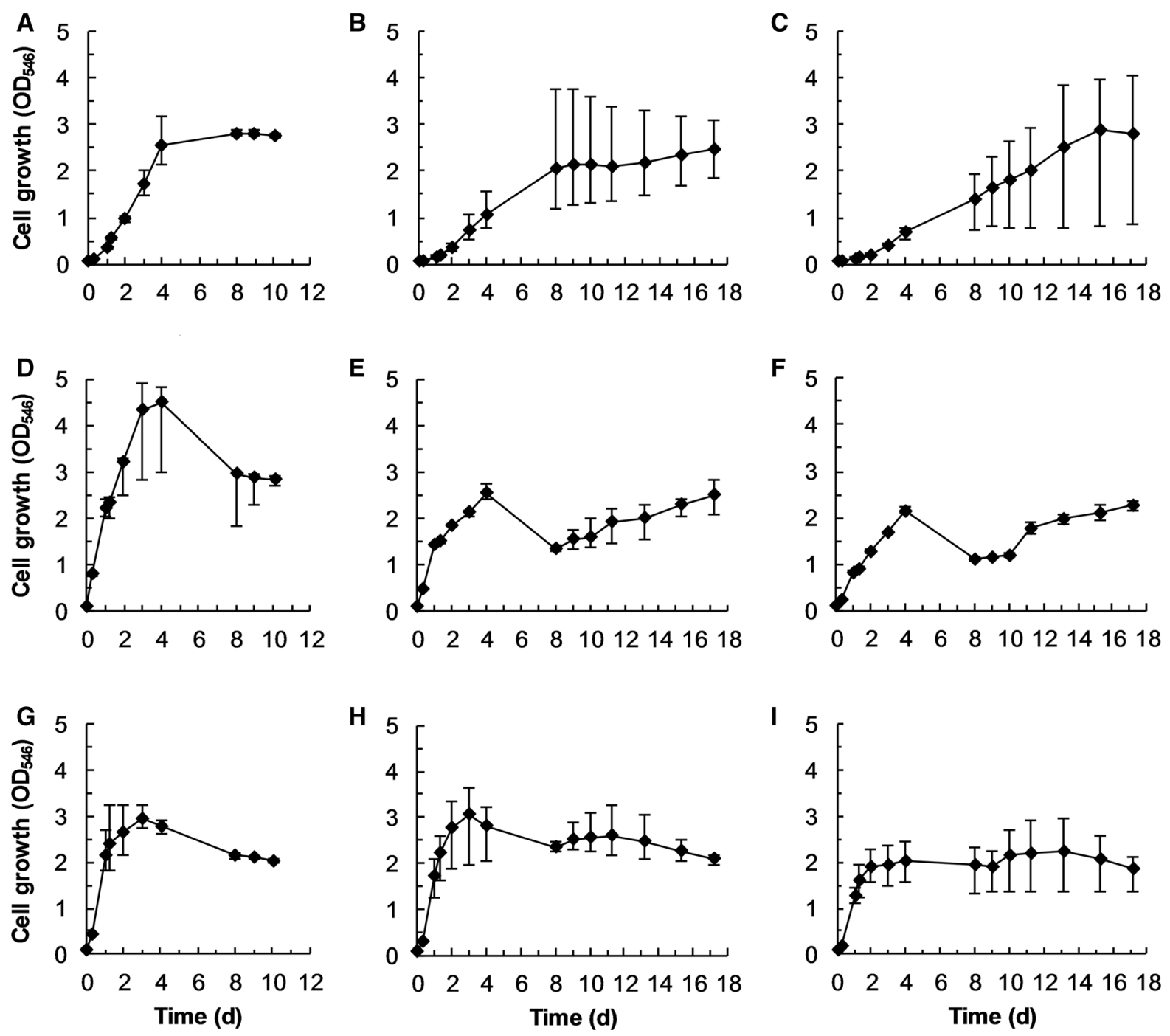

Fig. 5 Growth experiments were conducted in triplicate for strains BOE3, BOE100, and BOE200 at different 2-BE concentrations. A BOE3, $20 \mathrm{mM}$; B BOE3, $30 \mathrm{mM}$; C BOE3,

(Chen et al. 2010), 3- and 4-phenoxybenzoate (Dehmel et al. 1995; Engesser et al. 1990; Topp and Akhtar 1991; Wittich et al. 1990), dibenzo- $p$-dioxin, dibenzofuran, 1- and 2-monochlorodibenzo- $p$-dioxin (Hong et al. 2004), polymers like polyacrylate, polyhydroxyalkanoates, and polyvinyl alcohol (Kawai 2010), and more (Palleroni et al. 2010; Wackett 2003). Pseudomonads have also been described degrading PEG 400 (Pseudomonas sp. KW 8) (Watson and Jones 1977) or even PEG 13,500 (Pseudomonas stutzeri JA1001) (Obradors and Aguilar 1991). A PEG dehydrogenase was identified in the periplasm
40 mM; D BOE100, 30 mM; E BOE100, 40 mM; F BOE100, 50 mM; G BOE200, 20 mM; H BOE200, 30 mM; I BOE200, $40 \mathrm{mM}$

of strain JA1001. Activity of that enzyme was assayed by measuring the change in absorbance at $600 \mathrm{~nm}$ after the addition of 2,6-dichlorophenol-indophenol. PEG, diethylene glycol, and diglycolic acid were oxidized. Thus, the authors claim that this enzyme both oxidizes PEG and cleaves the ether bond. No further details are known about this enzyme such as molecular weight or amino acid sequence. Accordingly, no ether-cleaving genes have been identified in this genus and no degradation kinetics have been published. 
Table 3 Antibiotic resistance of strains BOE3, BOE100, and BOE200

\begin{tabular}{lllll}
\hline Antibiotic & Mass & \multicolumn{3}{l}{ Inhibition zone size $[\mathrm{mm}]$} \\
\cline { 3 - 5 } & $\mu \mathrm{g}$ & BOE3 & BOE100 & BOE200 \\
\hline Chloramphenicol & 64 & 32 & 12 & 17 \\
Tetracycline & 12 & 38 & 19 & 25 \\
Kanamycin & 50 & 60 & 22 & 24 \\
Ampicillin & 50 & 38 & 0 & 0 \\
Penicillin & 50 & 40 & 0 & 0 \\
Streptomycin & 50 & 58 & 16 & 20 \\
Nalidixic acid & 50 & 60 & 14 & 22 \\
\hline
\end{tabular}

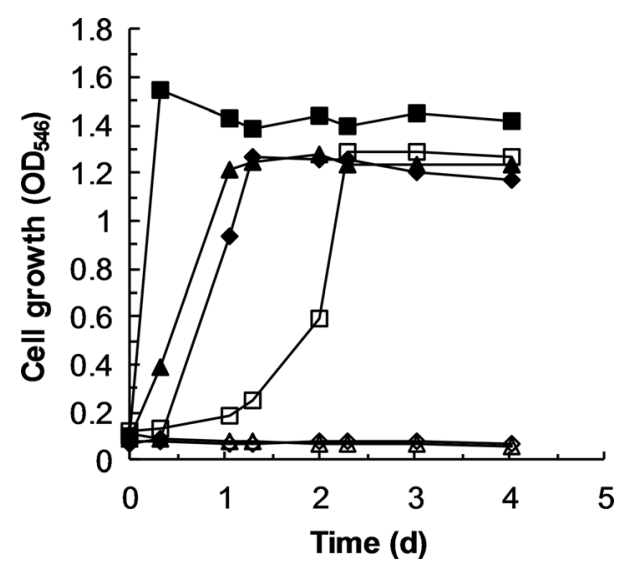

Fig. 6 Growth of BOE3, BOE100, and BOE200 in MMB with and without the addition of $3.5 \% \mathrm{NaCl}$. Filled diamonds: BOE3, $0 \% \mathrm{NaCl}$; open diamonds: $\mathrm{BOE} 3,3.5 \% \mathrm{NaCl}$; filled squares: BOE100, $0 \% \mathrm{NaCl}$; open squares: $\mathrm{BOE} 100,3.5 \% \mathrm{NaCl}$; filled triangles: BOE200, $0 \% \mathrm{NaCl}$; open triangles: BOE200, 3.5\% $\mathrm{NaCl}$
Yet, not every strain of the genus Pseudomonas is able to degrade 2-BE. We tested several pseudomonads from our strain collection for growth on 2-BE, including P. putida KT2440 (Bagdasarian et al. 1981), P. putida F1 (Zylstra et al. 1988), P. fluorescens DSM 56106, P. veronii MEK700 (Onaca et al. 2007), $P$. vancouverensis NCIMB 9816 (Kurkela et al. 1988), $P$. abietaniphila ATCC 17,483 (Barnsley 1976), and strains isolated from Annika Buchwald of our working group, Pseudomonas sp. BAL210 and Pseudomonas sp. BAL220. None of these strains were able to grow on 2-BE. Apparently, the ability to degrade 2-BE is strain-specific rather than species-specific.

To our knowledge, no strains of the genus $H y$ drogenophaga, Cupriavidus, or Gordonia have been described degrading EGEs like PEG or 2-BE. Nevertheless, other ethers such as AEs, aryl ethers, and alkyl aryl ethers are degraded by strains of these genera. For example, Gordonia spp. have been isolated growing on nonpolar 1,3- and 1,4-dialkoxybenzenes (Kim et al. 2007, 2008) or transforming ethyl $t$-butyl ether, MTBE, and $t$-amyl methyl ether most likely via the cytochrome P450 CYP249 yielding $t$-butyl alcohol or $t$-amyl alcohol, respectively (Malandain et al. 2010). Hydrogenophaga flava ENV735 is able to degrade MTBE (Hatzinger et al. 2001), and Hydrogenophaga atypical strain QY7-2 degrades 3-methyldiphenylether (Yang et al. 2016). Cupriavidus sp. WS degrades diphenyl ether, 4-bromodiphenyl ether, and 4,4'-bromodiphenyl ether (Wang et al. 2015). Cupriavidus pinatubonensis JMP134 (formerly Ralstonia eutropha, Alcaligenes eutrophus, and Cupriavidus necator JMP134) degrades 2,4-dichlorophenoxyacetic

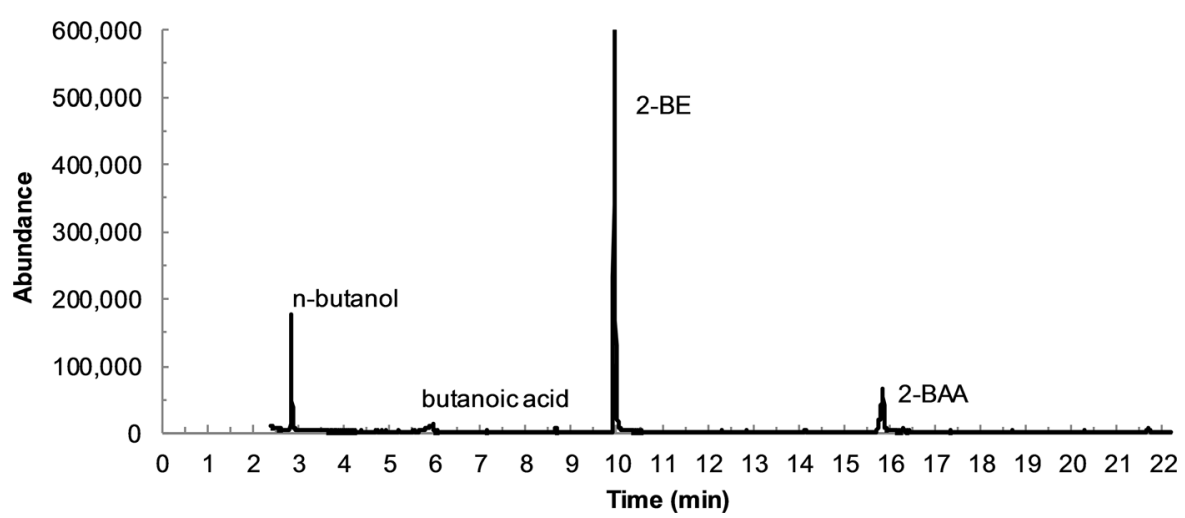

Fig. 7 GC-MS chromatogram of a DCM extract of a BOE100 culture grown in MMB after addition of Cm and incubation for another day showing the metabolites $n$-butanol, butanoic acid, and BAA as well as the substrate 2-BE 
acid (2,4-D) via 2,4-D/ $\alpha$-ketoglutarate dioxygenase (TfdA) forming 2,4-dichlorophenol and glyoxylate (Don et al. 1985; Hogan et al. 2000). 2,4-D and 2-BAA are structurally similar; instead of the butyl moiety there is a chlorinated phenyl moiety. However, it is not known if strain JMP134 is able to degrade 2-BE or PEG.

Apart from BOE5, none of the isolated BOE strains could grow on any of the nonpolar ethers diethyl ether, di- $n$-butyl ether, $n$-butyl vinyl ether, and dibenzyl ether. For this reason, it is unlikely that 2-BE degradation is mechanistically similar to the degradation of nonpolar ethers. On the contrary, all isolated strains were able to grow on 2-BE, 2-BAA, $n$-butanol, and glyoxylic acid. 2-BAA, $n$-butanol, and butanoic acid were detected in a culture of BOE100 growing on 2-BE after the addition of $\mathrm{Cm}$. These results lead to the assumption that the degradation of 2-BE by the isolated gram-negative strains proceeds via oxidation to 2-BAA and subsequent ether scission yielding butanol and glyoxylic acid, analogous to the degradation of PEG (Fig. 1, route 1).

The only known PEG degradation genes belong to strains Sphingopyxis terrae (GenBank accession no. AB239603), Sphingopyxis macrogoltabida strains 103 (AB196775) and 203 (AB239080), which share more than 99\% sequence identity (Somyoonsap et al. 2008; Tani et al. 2007), and Pseudonocardia sp. K1 (AB126017) (Yamashita et al. 2004b). In the Sphingopyxis strains mentioned, PEG is oxidized by PEG dehydrogenase PegA and aldehyde dehydrogenase PegC to PEG carboxylate. PCDH catalyzes the ether cleavage forming glyoxylate and PEG shortened by one ethylene glycol unit. In strain Pseudonocardia sp. $\mathrm{K} 1$, the degradation of PEG proceeds in the same manner, but by different enzymes. The ether is cleaved by DGADH, which has a high homology with superoxide dismutase.

None of the PEG degradation genes pegA, pegC, $p c d h$ or dgadh could be detected in the BOE strains by PCR (see Supplementary Material, supporting methods and Table S1). The primers used are, of course, very specific for the respective gene sequences. Therefore, it is still possible that the BOE strains use similar enzymes for the degradation of 2-BE. Further studies are necessary to identify these genes.
Degradation kinetics and 2-BE concentration limits were investigated for strains BOE3, BOE100, and BOE200. The maximum growth rate of BOE3 at $30{ }^{\circ} \mathrm{C}$ was $0.204 \mathrm{~h}^{-1}$, achieved at a concentration of $4 \mathrm{mM}$ 2-BE. The degradation of $4 \mathrm{mM}$ 2-BE took around $13 \mathrm{~h}$. At higher concentrations, growth rates decreased continuously. The concentration limit for a steady degradation seemed to be $20 \mathrm{mM}$ 2-BE which were consumed within 4 days. Concentrations higher than $20 \mathrm{mM}$ led to substantially inhibited growth.

The maximum growth rate of BOE200 was $0.395 \mathrm{~h}^{-1}$ at $6 \mathrm{mM} 2-\mathrm{BE}$ which were degraded within $12 \mathrm{~h} .20 \mathrm{mM}$ 2-BE were removed within 3 days. Higher concentrations led to accumulation of 2-BAA and a $\mathrm{pH}$ drop to 6 , and growth was strongly inhibited.

BOE100 grew the fastest and tolerated the highest substrate concentrations among the BOE strains. The maximum growth rate was $0.645 \mathrm{~h}^{-1}$ at a $2-\mathrm{BE}$ concentration of $5 \mathrm{mM}$, which were completely degraded within less than $6 \mathrm{~h}$. A stable degradation of 2-BE could be achieved for concentrations of up to $30 \mathrm{mM}$. Beyond that value, 2-BAA accumulated and the $\mathrm{pH}$ decreased to 6 , inhibiting further growth, similar to BOE200.

These findings support the already stated hypothesis, that 2-BE is oxidized to 2-BAA before the ether bond is cleaved. In strains BOE100 and BOE200, the subsequent reaction seems to be the rate-limiting step, as 2-BAA was detected in the medium.

This study is the first that gives information about different 2-BE degrading bacterial strains and about degradation kinetics, although 2-BE is a HPVC and widespread in the environment. It is the main component of Corexit EC9527A, of which 813,000 L were applied to the ocean surface during the 2010 Deepwater Horizon oil spill. As a result, large quantities of 2-BE have been, and still are, released into the environment. Among the isolated strains, BOE100 degrades 2-BE the fastest and tolerates the highest concentrations. Moreover, it is able to degrade 2-BE in medium containing $3.5 \% \mathrm{NaCl}$ corresponding to the salinity of seawater. Therefore, this strain is of great interest for a possible use in bioremediation.

Further studies are under way to identify the degradation genes and gain information about the enzyme kinetics. 
Acknowledgements Open Access funding provided by Projekt DEAL. This work was supported by the Landesgraduiertenförderung of the University of Stuttgart.

Open Access This article is licensed under a Creative Commons Attribution 4.0 International License, which permits use, sharing, adaptation, distribution and reproduction in any medium or format, as long as you give appropriate credit to the original author(s) and the source, provide a link to the Creative Commons licence, and indicate if changes were made. The images or other third party material in this article are included in the article's Creative Commons licence, unless indicated otherwise in a credit line to the material. If material is not included in the article's Creative Commons licence and your intended use is not permitted by statutory regulation or exceeds the permitted use, you will need to obtain permission directly from the copyright holder. To view a copy of this licence, visit http://creativecommons.org/licenses/by/4.0/.

\section{References}

Aasmoe L, Winberg JO, Aarbakke J (1998) The role of liver alcohol dehydrogenase isoenzymes in the oxidation of glycolethers in male and female rats. Toxicol Appl Pharmacol 150:86-90. https://doi.org/10.1006/taap.1998.8410

Altschul SF, Gish W, Miller W, Myers EW, Lipman DJ (1990) Basic local alignment search tool. J Mol Biol 215:403-410. https://doi.org/10.1016/S0022-2836(05)80360-2

Arias S, Olivera ER, Arcos M, Naharro G, Luengo JM (2008) Genetic analyses and molecular characterization of the pathways involved in the conversion of 2-phenylethylamine and 2-phenylethanol into phenylacetic acid in Pseudomonas putida U. Environ Microbiol 10:413-432. https://doi.org/10.1111/j.1462-2920.2007.01464.x

ATSDR (1998) Toxicological profile for 2-butoxyethanol and 2-butoxyethanol acetate. Agency for Toxic Substances and Disease Registry, U.S. Department of Health and Human Services, Public Health Service

Bagdasarian M, Lurz R, Rückert B, Franklin FCH, Bagdasarian MM, Frey J, Timmis KN (1981) Specific-purpose plasmid cloning vectors II. Broad host range, high copy number, RSF 1010-derived vectors, and a host-vector system for gene cloning in Pseudomonas. Gene 16:237-247. https:// doi.org/10.1016/0378-1119(81)90080-9

Barnsley EA (1976) Role and regulation of the ortho and meta pathways of catechol metabolism in pseudomonads metabolizing naphthalene and salicylate. J Bacteriol 125:404-408

Bartnik FG, Reddy AK, Klecak G, Zimmermann V, Hostynek JJ, Kunstler K (1987) Percutaneous absorption, metabolism, and hemolytic activity of $n$-butoxyethanol. Fundam Appl Toxicol 8:59-70. https://doi.org/10.1016/02720590(87)90100-X

Boatman R, Kelsey J, Ball N (2014) Acute toxicity classification for ethylene glycol mono- $n$-butyl ether under the Globally Harmonized System. Regul Toxicol Pharmacol 68:41-50. https://doi.org/10.1016/j.yrtph.2013.11.004
Bock C, Kroppenstedt RM, Diekmann H (1996) Degradation and bioconversion of aliphatic and aromatic hydrocarbons by Rhodococcus ruber 219. Appl Microbiol Biotechnol 45:408-410. https://doi.org/10.1007/s002530050704

BP Gulf Science Data (2014) Application of dispersants to surface oil slicks by aircraft and by boat in approved areas of the Gulf of Mexico from April 22, 2010 to final application on July 19, 2010. Distributed by: Gulf of Mexico Research Initiative Information and Data Cooperative (GRIIDC), Harte Research Institute, Texas A\&M University-Corpus Christi. doi:10.7266/N70G3HK6. https://data. gulfresearchinitiative.org/data/BP.x750.000:0017

Budnik I, Zembrzuska J, Lukaszewski Z (2016) Bacterial strains isolated from river water having the ability to split alcohol ethoxylates by central fission. Environ Sci Pollut Res 23:14231-14239. https://doi.org/10.1007/s11356-0166566-8

Chen J-M, Zhou Y-Y, Chen D-Z, Jin X-J (2010) A newly isolated strain capable of effectively degrading tetrahydrofuran and its performance in a continuous flow system. Bioresour Technol 101:6461-6467. https://doi.org/10. 1016/j.biortech.2010.03.064

Committee on Energy and Commerce U.S. House of Representatives (2011) Chemicals used in hydraulic fracturing

Corti A, D'Antone S, Solaro R, Chiellini E (1998) Degradation of poly(ethylene glycol)-based nonionic surfactants by different bacterial isolates from river water. J Environ Polym Degrad 6:121-131. https://doi.org/10.1023/A: 1021813312506

Dean BS, Krenzelok EP (2008) Clinical evaluation of pediatric ethylene glycol monobutyl ether poisonings. J Toxicol 30:557-563. https://doi.org/10.3109/15563659209017941

Dehmel U, Engesser K-H, Timmis KN, Dwyer DF (1995) Cloning, nucleotide sequence, and expression of the gene encoding a novel dioxygenase involved in metabolism of carboxydiphenyl ethers in Pseudomonas pseudoalcaligenes POB310. Arch Microbiol 163:35-41. https://doi.org/ 10.1007/BF00262201

Deisinger PJ, Boatman RJ (2004) In vivo metabolism and kinetics of ethylene glycol monobutyl ether and its metabolites, 2-butoxyacetaldehyde and 2-butoxyacetic acid, as measured in blood, liver and forestomach of mice. Xenobiotica 34:675-685. https://doi.org/10.1080/ 00498250412331281061

Dobslaw D, Woiski C, Engesser K-H (2010) Implementation of TA Luft 2002 in existing plants: a bioscrubber for combined waste air and waste water treatment. Chem Ing Tech 82:2161-2170. https://doi.org/10.1002/cite.201000030

Dobslaw D, Woiski C, Winkler F, Engesser K-H, Dobslaw C (2018) Prevention of clogging in a polyurethane foam packed biotrickling filter treating emissions of 2-butoxyethanol. J Clean Prod 200:609-621. https://doi.org/10. 1016/j.jclepro.2018.07.248

Don RH, Weightman AJ, Knackmuss HJ, Timmis KN (1985) Transposon mutagenesis and cloning analysis of the pathways for degradation of 2,4-dichlorophenoxyacetic acid and 3-chlorobenzoate in Alcaligenes eutrophus JMP134(pJP4). J Bacteriol 161:85-90

Engesser KH, Fietz W, Fischer P, Schulte P, Knackmuss H-J (1990) Dioxygenolytic cleavage of aryl ether bonds: 1,2dihydro-1,2-dihydroxy-4-carboxybenzophenone as 
evidence for initial 1,2-dioxygenation in 3- and 4-carboxy biphenyl ether degradation. FEMS Microbiol Lett 69:317-321. https://doi.org/10.1111/j.1574-6968.1990. tb04251.x

European Chemicals Bureau (2006) 2-Butoxyethanol (EGBE): Part I-environment. In: European Union Risk Assessment Report, vol 68

Gooch JW (ed) (2007) Encyclopedic dictionary of polymers. Springer, New York

Hatzinger PB, McClay K, Vainberg S, Tugusheva M, Condee CW, Steffan RJ (2001) Biodegradation of methyl tert-butyl ether by a pure bacterial culture. Appl Environ Microbiol 67:5601-5607. https://doi.org/10.1128/AEM.67.12.56015607.2001

Hogan DA, Smith SR, Saari EA, McCracken J, Hausinger RP (2000) Site-directed mutagenesis of 2,4-dichlorophenoxyacetic acid/alpha-ketoglutarate dioxygenase: identification of residues involved in metallocenter formation and substrate binding. J Biol Chem 275:12400-12409. https://doi. org/10.1074/jbc.275.17.12400

Hong H-B, Nam I-H, Murugesan K, Kim Y-M, Chang Y-S (2004) Biodegradation of dibenzo- $p$-dioxin, dibenzofuran, and chlorodibenzo- $p$-dioxins by Pseudomonas veronii $\mathrm{PH}$ 03. Biodegradation 15:303-313. https://doi.org/10.1023/B: BIOD.0000042185.04905.0d

Hosoya H, Miyazaki N, Sugisaki Y, Takanashi E, Tsurufuji M, Yamasaki M, Tamura G (1978) Bacterial degradation of synthetic polymers and oligomers with the special reference to the case of polyethylene glycol. Agric Biol Chem 42:1545-1552. https://doi.org/10.1271/bbb1961.42.1545

Hur H, Newman LM, Wackett LP, Sadowsky MJ (1997) Toluene 2-monooxygenase-dependent growth of Burkholderia cepacia G4/PR1 on diethyl ether. Appl Environ Microbiol 63:1606-1609

Hyman MR (1999) Final report: Aerobic cometabolism of etherbonded compounds. National Center for Environmental Research. EPA Grant Number: R823426. https://cfpub. epa.gov/ncer_abstracts/index.cfm/fuseaction/display. abstractDetail/abstract/673/report/F

IARC (2006) Volume 88: Formaldehyde, 2-Butoxyethanol and 1-tert-Butoxypropan-2-ol. In: IARC Monographs on the evaluation of carcinogenic risks to humans

Ichikawa Y, Kitamoto Y, Hosoi N (1978) Degradation of polyethylene glycol dodecyl ethers by a pseudomonad isolated from activated sludge. $\mathrm{J}$ Ferment Technol 56:403-409

Inoue D, Tsunoda T, Sawada K, Yamamoto N, Saito Y, Sei K, Ike M (2016) 1,4-Dioxane degradation potential of members of the genera Pseudonocardia and Rhodococcus. Biodegradation 27:277-286. https://doi.org/10.1007/ s10532-016-9772-7

Jindrová E, Chocová M, Demnerová K, Brenner V (2002) Bacterial aerobic degradation of benzene, toluene, ethylbenzene and xylene. Folia Microbiol 47:83-93. https://doi. org/10.1007/BF02817664

Johanson G, Johnsson S (1991) Gas chromatographic determination of butoxyacetic acid in human blood after exposure to 2-butoxyethanol. Arch Toxicol 65:433-435. https://doi. org/10.1007/BF02284269
Kaphalia BS, Ghanayem BI, Ansari GA (1996) Nonoxidative metabolism of 2-butoxyethanol via fatty acid conjugation in Fischer 344 rats. J Toxicol Environ Health 49:463-479

Kawai F (2010) The biochemistry and molecular biology of xenobiotic polymer degradation by microorganisms. Biosci Biotechnol Biochem 74:1743-1759. https://doi.org/ 10.1271/bbb.100394

Kawai F, Enokibara S (1996) Role of novel dye-linked dehydrogenases in the metabolism of polyethylene glycol by pure cultures of Sphingomonas sp. N6. FEMS Microbiol Lett 141:45-50. https://doi.org/10.1111/j.1574-6968.1996. tb08361.x

Kawai F, Yamanaka H (1986) Biodegradation of polyethylene glycol by symbiotic mixed culture (obligate mutualism). Arch Microbiol 146:125-129. https://doi.org/10.1007/ BF00402338

Kawai F, Yamanaka H (1989) Inducible or constitutive polyethylene glycol dehydrogenase involved in the aerobic metabolism of polyethylene glycol. J Ferment Bioeng 67:300-302. https://doi.org/10.1016/0922338X(89)90236-5

Kim Y-H, Engesser K-H (2004) Degradation of alkyl ethers, aralkyl ethers, and dibenzyl ether by Rhodococcus sp. strain DEE5151, isolated from diethyl ether-containing enrichment cultures. Appl Environ Microbiol 70:4398-4401. https://doi.org/10.1128/AEM.70.7.43984401.2004

Kim Y-H, Engesser K-H, Kim S-J (2007) Physiological, numerical and molecular characterization of alkyl etherutilizing rhodococci. Environ Microbiol 9:1497-1510. https://doi.org/10.1111/j.1462-2920.2007.01269.x

Kim Y-H, Cha C-J, Engesser K-H, Kim S-J (2008) Degradation of various alkyl ethers by alkyl ether-degrading Actinobacteria isolated from activated sludge of a mixed wastewater treatment. Chemosphere 73:1442-1447. https://doi.org/10.1016/j.chemosphere.2008.07.074

Kohlweyer U, Thiemer B, Schraeder T, Andreesen JR (2000) Tetrahydrofuran degradation by a newly isolated culture of Pseudonocardia sp. strain K1. FEMS Microbiol Lett 186:301-306. https://doi.org/10.1111/j.1574-6968.2000. tb09121.x

Kover SC, Rosario-Ortiz FL, Linden KG (2014) Photochemical fate of solvent constituents of Corexit oil dispersants. Water Res 52:101-111. https://doi.org/10.1016/j.watres. 2013.12.013

Kumar S, Stecher G, Tamura K (2016) MEGA7: molecular evolutionary genetics analysis version 7.0 for bigger datasets. Mol Biol Evol 33:1870-1874. https://doi.org/10. 1093/molbev/msw054

Kurkela S, Lehväslaiho H, Palva ET, Teeri TH (1988) Cloning, nucleotide sequence and characterization of genes encoding naphthalene dioxygenase of Pseudomonas putida strain NCIB9816. Gene 73:355-362. https://doi.org/10.1016/ 0378-1119(88)90500-8

Lockley DJ, Howes D, Williams FM (2004) Percutaneous penetration and metabolism of 2-butoxyethanol. Arch Toxicol 78:617-628. https://doi.org/10.1007/s00204-0040581-0

Malandain C, Fayolle-Guichard F, Vogel TM (2010) Cytochromes P450-mediated degradation of fuel oxygenates by environmental isolates. FEMS Microbiol Ecol 
72:289-296. https://doi.org/10.1111/j.1574-6941.2010. 00847.x

Martin B, Humbert O, Camara M, Guenzi E, Walker J, Mitchell T, Andrew P, Prudhomme M, Alloing G, Hakenbeck R, Morrison DA, Boulnois GJ, Claverys J-P (1992) A highly conserved repeated DNA element located in the chromosome of Streptococcus pneumoniae. Nucleic Acids Res 20:3479-3483. https://doi.org/10.1093/nar/20.13.3479

McClay K, Schaefer CE, Vainberg S, Steffan RJ (2007) Biodegradation of bis(2-chloroethyl) ether by Xanthobacter sp. strain ENV481. Appl Environ Microbiol 73:6870-6875. https://doi.org/10.1128/AEM.01379-07

Mooney A, Ward PG, O'Connor KE (2006) Microbial degradation of styrene: biochemistry, molecular genetics, and perspectives for biotechnological applications. Appl Microbiol Biotechnol 72:1. https://doi.org/10.1007/ s00253-006-0443-1

Moreno-Horn M, Garbe L-A, Tressl R, Görisch H (2005) Transient accumulation of gamma-butyrolactone during degradation of bis(4-chloro- $n$-butyl) ether by diethylethergrown Rhodococcus sp. strain DTB. Appl Microbiol Biotechnol 69:335-340. https://doi.org/10.1007/s00253005-1984-4

Obradors N, Aguilar J (1991) Efficient biodegradation of highmolecular-weight polyethylene glycols by pure cultures of Pseudomonas stutzeri. Appl Environ Microbiol 57:2383-2388

OECD (1997) SIDS Initial Assessment Report for 6th SIAM, 2-Butoxyethanol. Organization for Economic Cooperation and Development, Screening Information Data Set

OECD (2004) SIDS Initial Assessment Report for SIAM 19, Monoethylene Glycol Ethers Category. Organization for Economic Cooperation and Development, Screening Information Data Set

Onaca C, Kieninger M, Engesser K-H, Altenbuchner J (2007) Degradation of alkyl methyl ketones by Pseudomonas veronii MEK700. J Bacteriol 189:3759-3767. https://doi. org/10.1128/JB.01279-06

Palleroni NJ, Pieper DH, Moore ERB (2010) Microbiology of hydrocarbon-degrading Pseudomonas. In: Timmis KN (ed) Handbook of hydrocarbon and lipid microbiology. Springer, Berlin, pp 1787-1798

Panchenko LV, Turkovskaya OV (2000) Study of microbial degradation of nonionic surfactants in designing sewage purification technologies. Appl Biochem Microbiol 36:160-164. https://doi.org/10.1007/BF02737912

Parales RE, Adamus JE, White N, May HD (1994) Degradation of 1,4-dioxane by an actinomycete in pure culture. Appl Environ Microbiol 60:4527-4530

Patterson SJ, Scott CC, Tucker KBE (1967) Nonionic detergent degradation. I. Thin-layer chromatography and foaming properties of alcohol polyethoxylates. J Am Oil Chem Soc 44:407-412. https://doi.org/10.1007/BF02666780

Patterson SJ, Scott CC, Tucker KBE (1970) Nonionic detergent degradation: III. Initial mechanism of the degradation. J Am Oil Chem Soc 47:37-41. https://doi.org/10.1007/ BF02541454

Pearce BA, Heydeman MT (1980) Metabolism of di(ethylene glycol) [2-(2'-hydroxyethoxy)ethanol] and other short poly(ethylene glycol)s by gram-negative bacteria.
Microbiology 118:21-27. https://doi.org/10.1099/ 00221287-118-1-21

Peng R-H, Xiong A-S, Xue Y, Fu X-Y, Gao F, Zhao W, Tian Y-S, Yao Q-H (2008) Microbial biodegradation of polyaromatic hydrocarbons. FEMS Microbiol Rev 32:927-955. https://doi.org/10.1111/j.1574-6976.2008. 00127.x

Rambourg-Schepens MO, Buffet M, Bertault R, Jaussaud M, Journe B, Fay R, Lamiable D (1988) Severe ethylene glycol butyl ether poisoning. Kinetics and metabolic pattern. Hum Toxicol 7:187-189. https://doi.org/10.1177/ 096032718800700215

Rettenmeier AW, Hennigs R, Wodarz R (1993) Determination of butoxyacetic acid and $N$-butoxyacetyl-glutamine in urine of lacquerers exposed to 2-butoxyethanol. Int Arch Occup Environ Health 65:S151-S153. https://doi.org/10. 1007/BF00381329

Rojo F (2009) Degradation of alkanes by bacteria. Environ Microbiol 11:2477-2490. https://doi.org/10.1111/j.14622920.2009.01948.x

Saitou N, Nei M (1987) The neighbor-joining method: A new method for reconstructing phylogenetic trees. Mol Biol Evol 4:406-425. https://doi.org/10.1093/oxfordjournals. molbev.a040454

Schröder HF (2001) Tracing of surfactants in the biological wastewater treatment process and the identification of their metabolites by flow injection-mass spectrometry and liquid chromatography-mass spectrometry and -tandem mass spectrometry. J Chromatogr A 926:127-150. https://doi. org/10.1016/S0021-9673(01)00941-4

Schuster J, Purswani J, Breuer U, Pozo C, Harms H, Müller RH, Rohwerder T (2013) Constitutive expression of the cytochrome P450 EthABCD monooxygenase system enables degradation of synthetic dialkyl ethers in Aquincola tertiaricarbonis L108. Appl Environ Microbiol 79:2321-2327. https://doi.org/10.1128/AEM.03348-12

Somyoonsap P, Tani A, Charoenpanich J, Minami T, Kimbara K, Kawai F (2008) Involvement of PEG-carboxylate dehydrogenase and glutathione S-transferase in PEG metabolism by Sphingopyxis macrogoltabida strain 103 . Appl Microbiol Biotechnol 81:473-484. https://doi.org/10. 1007/s00253-008-1635-7

Sparham C, Rehman N, Melling J, van Duynhoven J, Marshall S (2008) Biodegradability of highly ethoxylated nonionic surfactants: determination of intermediates and pathways of biodegradation. Environ Toxicol Chem 27:1069-1076. https://doi.org/10.1897/07-476.1

Steber J, Wierich P (1985) Metabolites and biodegradation pathways of fatty alcohol ethoxylates in microbial biocenoses of sewage treatment plants. Appl Environ Microbiol 49:530-537

Szymanski A, Bubien E, Kurosz T, Wolniewicz A, Lukaszewski Z (2002a) Biodegradation of fatty alcohol ethoxylates under the conditions of the die-away test. Polish J Environ Stud 11:429-433

Szymanski A, Wyrwas B, Bubien E, Kurosz T, Hreczuch W, Zembrzuski W, Lukaszewski Z (2002b) Biodegradation of oxo-alcohol ethoxylates in the continuous flow activated sludge simulation test. Water Res 36:3378-3386. https:// doi.org/10.1016/S0043-1354(02)00035-0 
Tajima T, Hayashida N, Matsumura R, Omura A, Nakashimada Y, Kato J (2012) Isolation and characterization of tetrahydrofuran-degrading Rhodococcus aetherivorans strain M8. Process Biochem 47:1665-1669. https://doi.org/ 10.1016/j.procbio.2011.08.009

Takeuchi M, Kawai F, Shimada Y, Yokota A (1993) Taxonomic study of polyethylene glycol-utilizing bacteria: emended description of the genus Sphingomonas and new descriptions of Sphingomonas macrogoltabidus sp. nov., Sphingomonas sanguis sp. nov. and Sphingomonas terrae sp. nov. Syst Appl Microbiol 16:227-238. https://doi.org/10. 1016/S0723-2020(11)80473-X

Takeuchi M, Hamana M, Hiraishi A (2001) Proposal of the genus Sphingomonas sensu stricto and three new genera, Sphingobium, Novosphingobium and Sphingopyxis, on the basis of phylogenetic and chemotaxonomic analyses. Int $\mathbf{J}$ Syst Evol Microbiol 51:1405-1417. https://doi.org/10. 1099/00207713-51-4-1405

Tamura K, Nei M, Kumar S (2004) Prospects for inferring very large phylogenies by using the neighbor-joining method. Proc Natl Acad Sci USA 101:11030-11035. https://doi. org/10.1073/pnas.0404206101

Tani A, Charoenpanich J, Mori T, Takeichi M, Kimbara K, Kawai F (2007) Structure and conservation of a polyethylene glycol-degradative operon in sphingomonads. Microbiology 153:338-346. https://doi.org/10.1099/mic.0. 2006/000992-0

Thélu J, Medina L, Pelmont J (1980) Oxidation of polyoxyethylene oligomers by an inducible enzyme from Pseudomonas P 400. FEMS Microbiol Lett 8:187-190. https://doi.org/10.1111/j.1574-6968.1980.tb05076.x

Thiemer B, Andreesen JR, Schräder T (2003) Cloning and characterization of a gene cluster involved in tetrahydrofuran degradation in Pseudonocardia sp. strain K1. Arch Microbiol 179:266-277. https://doi.org/10.1007/s00203003-0526-7

Tidswell EC, Russell NJ, White GF (1996) Ether-bond scission in the biodegradation of alcohol ethoxylate nonionic surfactants by Pseudomonas sp. strain SC25A. Microbiology 142:1123-1131. https://doi.org/10.1099/13500872-142-51123

Tobin RS, Onuska FI, Brownlee BG, Anthony DHJ, Comba ME (1976) The application of an ether cleavage technique to a study of the biodegradation of a linear alcohol ethoxylate nonionic surfactant. Water Res 10:529-535. https://doi. org/10.1016/0043-1354(76)90190-1

Topp E, Akhtar MH (1991) Identification and characterization of a Pseudomonas strain capable of metabolizing phenoxybenzoates. Appl Environ Microbiol 57:1294-1300

Udden MM, Patton CS (1994) Hemolysis and deformability of erythrocytes exposed to butoxyacetic acid, a metabolite of 2-butoxyethanol: I. Sensitivity in rats and resistance in normal humans. J Appl Toxicol 14:91-96. https://doi.org/ 10.1002/jat.2550140206

U.S. EPA (2010) Toxicological review of ethylene glycol monobutyl ether (EGBE) (CAS No. 111-76-2). In: Support of summary information on the integrated risk information system (IRIS), Washington, DC. https://cfpub.epa.gov/ ncea/iris_drafts/recordisplay.cfm?deid=237120

van Beilen JB, Funhoff EG (2007) Alkane hydroxylases involved in microbial alkane degradation. Appl Microbiol
Biotechnol 74:13-21. https://doi.org/10.1007/s00253-0060748-0

Vainberg S, McClay K, Masuda H, Root D, Condee C, Zylstra GJ, Steffan RJ (2006) Biodegradation of ether pollutants by Pseudonocardia sp. strain ENV478. Appl Environ Microbiol 72:5218-5224. https://doi.org/10.1128/AEM.0016006

Versalovic J, Schneider M, de BruijnLupski FJJR (1994) Genomic fingerprinting of bacteria using repetitive sequence-based polymerase chain reaction. Methods Mol Cell Biol 5:25-40

Wackett LP (2003) Pseudomonas putida: a versatile biocatalyst. Nat Biotechnol 21:136-138. https://doi.org/10.1038/ nbt0203-136

Wang S, Bai N, Wang B, Feng Z, Hutchins WC, Yang C-H, Zhao Y (2015) Characterization of the molecular degradation mechanism of diphenyl ethers by Cupriavidus sp. WS Environ Sci Pollut Res 22:16914-16926. https://doi. org/10.1007/s11356-015-4854-3

Wang Y, Nie M, Wan Y, Tian X, Nie H, Zi J, Ma X (2017) Functional characterization of two alkane hydroxylases in a versatile Pseudomonas aeruginosa strain NY3. Ann Microbiol 67:459-468. https://doi.org/10.1007/s13213017-1271-5

Watson GK, Jones N (1977) The biodegradation of polyethylene glycols by sewage bacteria. Water Res 11:95-100. https:// doi.org/10.1016/0043-1354(77)90189-0

Weisburg WG, Barns SM, Pelletier DA, Lane DJ, Weisburg WG, Barns SM, Pelletier DA, Lane DJ (1991) 16S ribosomal DNA amplification for phylogenetic study. J Bacteriol 173:697-703. https://doi.org/10.1128/jb.173.2.697703.1991

Wittich R-M, Schmidt S, Fortnagel P (1990) Bacterial degradation of 3- and 4-carboxybiphenyl ether by Pseudomonas sp. NSS2. FEMS Microbiol Lett 67:157-160. https://doi. org/10.1111/j.1574-6968.1990.tb13854.x

Yamanaka H, Kawai F (1991) Purification and characterization of a glycolic acid (GA) oxidase active toward diglycolic acid (DGA) produced by DGA-utilizing Rhodococcus sp. No. 432. J Ferment Bioeng 71:83-88. https://doi.org/10. 1016/0922-338X(91)90228-9

Yamashita M, Tani A, Kawai F (2004a) A new ether bondsplitting enzyme found in Gram-positive polyethylene glycol 6000-utilizing bacterium, Pseudonocardia sp. strain K1. Appl Microbiol Biotechnolk 66:174-179. https://doi. org/10.1007/s00253-004-1709-0

Yamashita M, Tani A, Kawai F (2004b) Cloning and expression of an ether-bond-cleaving enzyme involved in the metabolism of polyethylene glycol. J Biosci Bioeng 98:313-315. https://doi.org/10.1016/S13891723(04)00289-0

Yang Q, Cai S, Dong S, Chen L, Chen J, Cai T (2016) Biodegradation of 3-methyldiphenylether (MDE) by $\mathrm{Hy}$ drogenophaga atypical strain QY7-2 and cloning of the methy-oxidation gene $m d e A B C D$. Sci Rep 6:39270. https:// doi.org/10.1038/srep39270

Zembrzuska J, Budnik I, Lukaszewski Z (2016) Parallel pathways of ethoxylated alcohol biodegradation under aerobic conditions. Sci Total Environ 557-558:612-619. https:// doi.org/10.1016/j.scitotenv.2016.03.112 
Zylstra GJ, McCombie WR, Gibson DT, Finette BA (1988)

Toluene degradation by Pseudomonas putida F1: genetic organization of the tod operon. Appl Environ Microbiol 54:1498-1503
Publisher's Note Springer Nature remains neutral with regard to jurisdictional claims in published maps and institutional affiliations. 